\title{
PENGARUH PARTISIPASI PENYUSUNAN ANGGARAN, GAYA KEPEMIMPINAN DAN MOTIVASI TERHADAP KINERJA MANAJERIAL
}

\author{
Roza Umami \\ roza.um1995@gmail.com \\ Universitas Jambi
}

\begin{abstract}
ABSTRAK
Penelitian ini bertujuan untuk menguji pengaruh variabel partisipasi penyusunan anggaran, gaya kepemimpinan dan motivasi terhadap kinerja manajerial pada Kantor Wilayah Kementrian Agama Provinsi Jambi. Penelitian ini menggunakan teknik purposive sampling. Pengumpulan data penelitian dilakukan dengan menyebarkan kuesioner kepada 41 responden, dan kuesioner yang dapat digunakan hanya sebanyak 41. Pengolahan data menggunakan software SPSS 22.0. Sebelum pengujian hipotesis, dilakukan uji kualitas instrumen dan uji asumsi klasik. Hasil pengujian kualitas instrumen yang terdiri dari uji validitas dan reliabilitas menunjukkan bahwa semua item pertanyaan adalah valida dan reliabel. Hasil pengujian asumsi klasik yang terdiri dari uji normalitas data, uji multikolinearitas, dan uji heteroskedastisitas menunjukkan bahwa semua data telah memenuhi syarat. Hasil pengujian hipotesis menunjukkan bahwa secara simultan partisipasi penyusunan anggaran, gaya kepemimpinan dan motivasi berpengaruh terhadap kinerja manajerial. Secara parsial, partisipasi penyusunan anggaran, gaya kepemimpinan dan motivasi juga berpengaruh terhadap kinerja manajerial.
\end{abstract}

Kata kunci: partisipasi penyusunan anggaran, gaya kepemimpinan, motivasi, kinerja manajerial.

\section{PENDAHULUAN}

Negara Indonesia menganut sistem desentralisasi dimana pemerintah daerah diberikan kebebasan dan keleluasan untuk mengelola dan bertanggungjawab terhadap daerahnya masing-masing melalui otonomi daerah. Otonomi daerah merupakan hak, kewenangan, dan kewajiban suatu daerah untuk mengurus dan mengatur daerahnya sendiri tanpa campur tangan pemerintah pusat sehingga daerah tersebut lebih mandiri dan pembangunan nasional menjadi lebih maju (Wulandari \& Riharjo, 2016).Paradigma baru manajemen kepemerintahan berorientasi pada manajemen pemerintahan berbasis kinerja. Sebagai salah satu implementasi dari manajemen berbasis kinerja, maka dilaksanakan kewajiban pertanggungjawaban yang dimulai dari perencanaan, pelaksanaan dan pengendalian atas tugas dan fungsi pemerintah yang diwujudkan dengan penganggaran berbasis kinerja. Dalam penganggaran berbasis kinerja mengaitkan jumlah alokasi dana yang digunakan dalam setiap kegiatan sehingga menghasilkan keluaran (output) yang terdapat dalam target kinerja setiap unit kerja dan hasil yang diharapkan (outcome) termasuk efisiensi dalam pencapaian hasil keluaran tersebut. Sistem penganggaran pemerintah digunakan untuk melayani berbagai tujuan yaitu rencana manajemen, pengendalian keuangan, prioritas dari penggunaan dana, dan pertanggungjawaban kepada publi (Wulandari \& Riharjo, 2016).

Anggaran sektor publik dibuat untuk menentukan kebutuhan masyarakat, mengarahkan perkembangan sosial dan ekonomi yang nantinya akan berpengaruh terhadap 
meningkatnya kesejahteraan masyarakat. Anggaran sangat diperlukan karena kebutuhan masyarakat yang tidak terbatas sedangkan sumber pendapatannya terbatas, sehingga pemerintah harus merencanakan tujuan yang akan dicapai (Wulandari \& Riharjo, 2016).Partisipasi anggaran merupakan kegiatan yang mempunyai otoritas dalam penyusunan anggaran untuk mempersiapkan dan mengevaluasi berbagai alternatif serta tujuan anggaran. Adanya keterlibatan dalam proses perumusan tujuan anggaran sampai disetujui tersebut, akan mendorong pihak yang terlibat untuk bertanggungjawab terhadap masing-masing tugas sehingga meningkatkan kinerjanya agar dapat mencapai sasaran atau target, karena kinerja dinilai berdasarkan pencapaian target anggaran (Wulandari \& Riharjo, 2016).

gaya kepemimpinan merupakan norma prilaku yang digunakan oleh seseorang pada saat orang tersebut mencoba mempengaruhi prilaku orang lain atau bawahan. gaya kepemimpinan adalah sifat, kebiasaan, tempramen, watak dan kepribadian yang membedakan seorang pemimpin dalam berinteraksi dengan orang lain. Dengan demikian dapat disimpulkan bahwa gaya kepemimpinan adalah kegiatan pemimpin untuk mempengaruhi, memotivasi, mengarahkan dan mengendalikan para bawahannya sehingga tujuan organisasi dapat tercapai. Gaya kepemimpinan memiliki peran yang sangat penting karena dapat memberikan dampak positif maupun dampak negatif terhadap kinerja yang dipimpinnya. (Wulandari \& Riharjo, 2016).

(P.robbins \& A.judge, 2015) motivasi merupakan suatu proses yang menjelaskan mengenai kekuatan, arah dan ketekunan seseorang dalam upaya untuk mencapai tujuan. Motivasi secara umum adalah berkaitan dengan upaya menuju setiap tujuan organisasi.Motivasi erat hubungannya dengan timbulnya suatu kecenderungan untuk berbuat sesuatu guna mencapai tujuan.Motivasi timbul karena adanya suatu kebutuhan dan karenanya kebutuhan terebut terarah pada pencapaian tujuan tertentu. Apabila tujuan telah tercapai, maka akan tercapai kepuasan dan cenderung untuk diulang kembali, sehingga akan lebih kuat. Menurut (P.robbins \& A.judge, 2015) menyebutkan bahwa kekuatan kecenderungan kita untuk bertindak dengan cara tertentu bergantung pada kekuatan ekspektansi kita mengenai hasil yang diberikan dan ketertarikannya. Dalam hal yang lebih praktis, para pekerja akan mengarahkan pada penilaian kinerja yang baik, yang mana penilaian kinerja yang baik akan mengarahkan pada imbalan organisasi, misalnya peningkatan gaji. Menurut (Dewi, Putra, \& Merawati, 2017) Kinerja manajerial adalah seberapa efektif dan efisien manajer telah bekerja untuk mencapai tujuan organisasi, bahwa kinerja berdasarkan pada kemampuan manajer dalam melaksanakan tugas manajerial. Kinerja manajerial meliputi kemampuan manajer dalam perencanaan, investigasi, pengkoordinasian, evaluasi, pengawasan, pemilihan staff, negosiasi, dan perwakilan. (Apriansyah, Zirman, \& Rusli, 2014) Kinerja manajerial merupakan suatu proses pelaksanaan fungsi-fungsi manajemen, di dalamnya terdapat interaksi antara bawahan dengan atasan yang berkaitan dengan usaha dan kegiatan untuk merencanakan, mengarahkan dan mengendalikan prestasi kerja karyawan.

Partisipasi Penyusunan Anggaran dengan kinerja manajerial dapat dilihat dari beberapa penelitian berikut ini. Dalam penelitian (Dewi et al., 2017) menunjukkan bahwa partisipasi penyusunan anggaran berpengaruh positif terhadap kinerja manajerial. Hal ini menunjukkan bahwa semakin tinggi keterlibatan para manajer dalam penyusunan anggaran maka kinerja manajerial akan semakin meningkat. Hasil ini sejalan dengan pendapat (Wulandari \& Riharjo, 2016), (Yani, 2017). Namun penelitian lain yang menunjukkan bahwa partisipasi penyusunan anggaran tidak berpengaruh terhadap kinerja manajerial yaitu (Sari, 2013) dalam penelitiannya membuktikan bahwa hasil pengujian hipotesis menunjukkan hubungan antara partisipasi anggaran dan kinerja manajerial secara tidak langsung tidak mempunyai pengaruh yang signifikan. Hasil penelitian (Wulandari \& Riharjo, 2016) menyatakan bahwa gaya kepemimpinan berpengaruh positif terhadap kinerja manajerial. Hal 
ini dapat disimpulkan bahwa gaya kepemimpinan pengaruh pada partisipasi penyusunan anggaran terhadap kinerja manjerial. Jadi, semakin baik gaya kepemimpinan akan meningkatkan partisipasi penyusunan anggaran. Hasil ini sejalan dengan penelitian yang dilakukan oleh (Himawan \& Ika, 2010).

Peneliti mereplikasi ini karena adanya inkonsistensi hasil dalam beberapa penelitian terdahulu. Banyak penelitian yang memberikan kesimpulan berbeda ,(Sari, 2013) dalam penelitiannya menyatakan partisipasi anggaran secara parsial tidak memiliki pengaruh terhadap kinerja manajerial. Hasil tersebut menunjukkan bahwa partisipasi anggaran arahnya negatif. Namun hasil yang berbeda dalam penelitian yang dilakukan oleh (Wulandari \& Riharjo, 2016), dan (Yani, 2017) yang menemukan bahwa partisipasi anggaran berpengaruh terhadap kinerja manajerial namun dalam arah yang positif. (Wulandari \& Riharjo, 2016) menunjukkan bahwa gaya kepemimpinan berpengaruh posotif terhadap kinerja manajerial. Hal ini dapat disimpulkan bahwa gaya kepemimpinan dapat pengaruh partisipasi penyusunan anggaran terhadap kinerja manajerial. Jadi, semakin baik gaya kepemimpinan akan meningkatkan partisipasi penyusunan anggaran sehingga kinerja manajerial juga akan meningkat.

Alasan lain yang mendorong peneliti untuk melakukan pengembangan penelitian ini karena adanya inkonsistensi hasil penelitian adalah karena adanya fenomena masalah terkait dengan variabel-variabel dalam penelitian ini. Salah satunya yaitu variabel partisipasi penyususnan anggaran. Anggaran merupakan bagian yang penting untuk perencanaan efektif jangka pendek dan kontrol dalam organisasi. Penyelenggaraan anggaran biasanya meliputi waktu satu tahun dan menyatakan pemasukan dan pengeluaran selama satu tahun itu. (R. N. Anthony \& Govindarajan, 2003). Kantor wilayah Kementrian Agama Provinsi Jambi menyatakan realisasi anggaran kantor wilayah kementrian agama provinsi pada tahun 2016 rata-rata sebesar 91,79\%. Capaian tersebut menurun dibandingkan dengan capaian tahun 2015 sebesar $98,41 \%$. Karena adanya penerapan partisipasi anggaran yang kurang baik,sehingga terdapat beberapa kegiatan tidak dapat dilaksanakan, dimana pada tahun 2016 pada kementrian agama khususnya Kantor Wilayah Kementrian Agama Provinsi Jambi terjadi penghematan sebanyak dua kali (lakipkanwiljambi.kemenag.in). hal ini menunjukkan bahwa kurang adanya penerapan partisipasi dalam penyusunan anggaran di Kantor Wilayah Kementrian Agama Provinsi Jambi.

Kantor wilayah Kementrian Agama Provinsi Jambi memiliki tugas perumusan dan penetapan visi, misi, dan kebijakan teknis dibidang pelayanan dan bimbingan kehidupan beragama kepada masyarakat di provinsi. Pelayanan, bimbingan, dan pembinaan di bidang haji dan umrah. Pelayanan, bimbingan, dan pembinaan kerukunan umat beragama. Perumusan kebijakan teknis dibidang pengelolaan administrasi dan informasi. Pengkoordinasi perencanaan, pengendalian, pengawasan, dan evaluasi program. Pelaksanaan hubungan dengan pemerintah daerah, instansi terkait, dan lembaga masyarakat dalam rangka pelaksanaan tugas kementrian di provinsi. (jambi.kemenag.go.id).

Penelitian ini memiliki beberapa perbedaan dengan penelitian sebelumnya yang dilakukan oleh (Dewi et al., 2017). Perbedaan pertama dengan penelitian sebelumnya yaitu adanya penggantian varibel yaitu komitmen organisasi diganti dengan Gaya Kepemimpinan dengan alasan komitmen organiasi pada penelitian sebelumnya tidak berpengaruh partisipasi penyusunan anggaran terhadap kinerja manjerial. peneliti sebelumnya menggunakan partisipasi penyusunan anggaran, komitmen organisasi dan motivasi terhadap kinerja manjerial, sedangkan penelitian ini menambah variabel lain yaitu Gaya kepemimpinan. Alasan digantinya dengan gaya kepeimpinan yaitu sesuai dengan saran penelitian sebelumnya yaitu menambah variabel gaya kepemimpinan.Selanjutnya perbedaan kedua, perbedaan tempat penelitian. Penelitian terdahulu melakukan penelitian pada lembaga perkreditan desa 
LPD kota denpasar. Sedangkan pada penelitian ini akan dilakukan di kantor wilayah kementrian agama provinsi jambi.

Alasan peneliti memilih objek di Kantor Wilayah Kementrian Agama Provinsi Jambi karena adanya fenomena masalah terkait Gaya Kepemimpinan yang memiliki beberapa indikator diantaranya yaitu, hubungan antara atasan dan bawahan. Hal tersebut dikuatkan dengan teori yang diungkapkan oleh (Wulandari \& Riharjo, 2016). Gaya Kepemimpinan adalah perilaku atau cara yang dipilih dan dipergunakan pemimpin dalam mempengaruhi pikiran, perasaan, sikap dan perilaku para anggota organisasi bawahannya. Fakta yang terjadi pada Kantor Wilayah Kementrian Agama Provinsi Jambi berdasarkan wawancara dengan bapak Thoif selaku kepala bidang bagian informasi dan hubungan masyarakat mengatakan bahwa kurangnya komunikasi antara atasan terhadap bawahan. hal ini dapat dilihat masih lemahnya gaya kepemimpinan yang diberikan oleh atasan terhadap bawahan pada Kantor Wilayah Kementrian Agama Provinsi Jambi. alasan lainnya adalah peneliti ingin menguji secara empiris apakah ada pengaruh partisipasi penyusunan anggaran, gaya kepemimpinan dan motivasi terhadap kinerja manajerial.

Kantor Wilayah Kementerian Agama Provinsi Jambi adalah instansi pemerintah tingkat eselon II vertical yang berada di Kota Provinsi yang melaksanakan kebijakan dan bertanggungjawab kepada Menteri Agama secara langsung sebagaimana amanat Peraturan Menteri Agama Nomor 13 Tahun 2012. Pelaporan Akuntabilitas Kinerja Instansi Pemerintah (LAKIP) merupakan instrumen pertanggungjawaban kinerja yang berdasarkan pada Rencana Kinerja Tahun 2016 yang disampaikan kepada pimpinan unit organisasi Sebagaimana tertuang dalam Pasal 144 ayat (1) dan (2) Peraturan Menteri Agama Nomor 13 Tahun 2012 secara internal, Kantor Wilayah Kementerian Agama Provinsi Jambi memiliki susunan organisasi yang terdiri dari Bagian Tata Usaha, Bidang Pendidikan Madrasah, Bidang Pendidikan Agama dan Keagamaan Islam, Bidang Penyelenggaraan Haji dan Umrah, Bidang Urusan Agama Islam dan Pembinaan Syariah, Bidang Penerangan Agama Islam, Zakat, dan Wakaf, Pembimbing Masyarakat Kristen, Katolik, Hindu, Buddha dan Kelompok Jabatan Fungsional serta membawahi 11 (sebelas) Kantor Kementerian Agama Kabupaten dan Kota. Adapun Kantor Kementerian Kab/Kota yakni Kota Sungai Penuh, Kab. Kerinci, Kabupaten Batang Hari, Kabupaten Tanjung Jabung Barat, Kabupaten Bungo, Kabupaten Merangin, Kota Jambi, Kabupaten Muaro Jambi, Kabupaten Sarolangun, Kabupaten Tanjung Jabung Timur dan Kabupaten Tebo (www.lakipkanwiljambi.kemenag.in)

\section{LANDASAN TEORI DAN HIPOTESIS \\ Partisipasi Dalam Penyusunan Anggaran}

Partisipasi sebagai suatu proses dalam pembuatan keputusan bersama yang dilakukan oleh dua atau lebih anggota organisasi dimana keputusan tersebut dapat memiliki pengaruh terhadap mereka yang menghasilkan keputusan tersebut (Mulyadi, 2001). Sedangkan menurut Harahap (2008), partisipasi ialah suatu proses pengambilan keputusan bersama oleh dua pihak atau lebih yang mempunyai dampak masa depan bagi pembuat dan penerima keputusan tersebut. Brownell dalam Nor (2007) menjelaskan partisipasi sebagai suatu proses mengevaluasi para individu dan menetapkan penghargaan atas dasar sasaran anggaran yang telah dicapai serta keterlibatan dan pengaruh individu dalam penyusunan anggaran. Partisipasi dalam penyusunan anggaran lebih memungkinkan bagi para manajer untuk melakukan negosiasi dgn atasan mereka mengenai kemungkinan target anggaran yang dapat dicapai (Brownell dan Mcclnnes dalam Nor (2007). 


\section{Gaya Kepemimpinan}

Gaya kepemimpinan adalah sikap dan tindakan yang dilakukan pemimpin dalam menghadapi bawahan. Dengan adanya gaya kepemimpinan seorang pemimpin yang tegas dan bijak dapat mempengaruhi kemajuan suatu perusahaan, karena dengan pemimpin seperti itu akan disegani oleh bawahannya dan dapat memberikan motivasi kepada bawahannya untuk dapat memberikan yang terbaik untuk perusahaan tersebut. Untuk menjadi seorang pemimpin yang baik dalam perusahaan maka dibutuhkan kerjasama yang baik antara bawahan dengan pemimpin, karena dengan adanya kerjasama yang baik antara pemimpin dengan bawahan maka akan dapat mempengaruhi perusahaan berkembang lebih baik.

\section{Motivasi}

Motivasi merupakan suatu proses yang menjelaskan mengenai kekuatan, arah dan ketekunan seseorang dalam upaya untuk mencapai tujuan. Motivasi secara umum adalah berkaitan dengan upaya menuju setiap tujuan organiasai (Ni ketut sari sukma dewi,dkk, 2017). Di sisi lain Ranupandojo dan Husnan (2000) mendefinisikan motivasi sebagai proses untuk mencoba mempengaruhi seseorang agar melakukan sesuatu yang kita inginkan. Senada dengan pendapat di atas Hasibuan (2000) mendefinisikan motivasi adalah pemberian daya penggerak yang menciptakan kegairahan kerja seseorang agar mau bekerja sama, bekerja efektif dan terintegrasi dengan segala daya upayanya untuk mencapai kepuasan. Pendapat lainnya adalah menurut Edwin B Flippo dalam Hasibuan (2000) mendefinisikan motivasi sebagai suatu keahlian, dalam mengarahkan pegawai dan organisasi agar mau bekerja secara berhasil, sehingga keinginan para pegawai dan organisasi agar mau bekerja secara berhasil, sehingga keinginan para pegawai dan tujuan organisasi sekaligus tercapai.

\section{Kinerja Manajerial}

Mardiyah dan Listianingsih (2005) menyatakan kinerja (performance) adalah hasil kerja yang dapat dicapai oleh seseorang atau sekelompok orang dalam satu organisasi, sesuai dengan wewenang dan tanggung jawab masing-masing dalam rangka mencapai tujuan organisasi. Kinerja manajerial merupakan salah satu faktor yang dapat meningkatkan keefektifan organisasi.

\section{METODE PENELITIAN \\ Objek Penelitian}

Objek penelitian ini adalah partisipasi penyusunan anggaran, gaya kepemimpinan dan motivasi terhadap kinerja manajerial. Lokasi penelitian ini merupakan tempat melakukan kegiatan penelitian guna memperoleh data yang berasal dari responden. Lokasi penelitian ini adalah di Kantor Wilayah Kementrian Agama Provinsi Jambi.

\section{Populasi dan Sampel Penelitian}

populasi adalah seluruh kumpulan elemen yang menunjukkan ciri-ciri tertentu yang dapat digunakan untuk membuat kesimpulan. Berdasarkan pengertian di atas, maka jelaslah populasi bukan sekedar jumlah yang ada pada objek atau subjek yang dipelajari, tetapi meliputi seluruh karakteristik atau sifat yang dimiliki oleh subjek atau objek tersebut. Populasi dalam penelitian ini adalah seluruh karyawan yang bekerja di Kantor Wilayah Kementrian Agama sejumlah 141 karyawan.

\section{Jenis dan Sumber Data}

Jenis data yang digunakan dalam penelitian ini adalah data primer, yaitu sumber data penelitian yang diperoleh secara langsung dari sumber asli tanpa melalui media perantara. 
Data yang digunakan dalam penelitian ini merupakan data primer, diperoleh dengan cara pemberian daftar pertanyaan kepada responden dan mengirim kuesioner pada sampel yang telah ditentukan.

\section{Definisi Operasional Variabel}

Variabel adalah suatu atribut atau sifat atau nilai dari orang, objek atau kegiatan yang mempunyai variasi tertentu yang ditetapkan oleh peneliti untuk dipelajari dan ditarik kesimpulannya (Sugiyono, 2011). Variabel yang digunakan dalam penelitian ini adalah variabel bebas (Independen) dan variabel terikat (Dependen).

\section{Metode Analisis Data Statistik Deskriptif}

Statistik deskriptif memberikan gambaran atau deskripsi suatu data yang dilihat dari nilai rata-rata (mean), standar deviasi, varian, maksimum, minimum, sum, range, kurtosis dan skewness (kemencengan distribusi) (Ghozali, 2011).

\section{Uji Validitas}

Uji validitas digunakan untuk mengukur sah atau valid tidaknya suatu kuesioner. Suatu kuesioner dikatakan valid jika pertanyaan pada kuesioner mampu untuk mengungkapkan sesuatu yang akan diukur oleh kuesioner tersebut. Jadi validitas ingin mengukur apakah pertanyaan dalam kuesioner yang sudah kita buat betul betul dapat mengukur apa yang hendak kita ukur (Ghozali, 2016).

\section{Uji Reabilitas}

(Ghozali, 2016) menyatakan bahwa reliabilitas adalah alat untuk mengukur suatu kuesioner yang merupakan indikator dari variabel atau konstruk. Suatu kuesioner dikatakan reliabel atau handal jika jawaban seseorang terhadap pertanyaan adalah konsisten atau stabil dari waktu ke waktu. Pengujian reliabilitas yang digunakan dalam penelitian ini adalah One Shot atau pengukuran sekali saja, dimana pengukurannya hanya sekali dan kemudian hasilnya dibandingkan dengan pertanyaan lain atau mengukur korelasi antar jawaban pertanyaan. Reliabilitas diukur dengan uji statistik Cronbach Alpha. Suatu konstruk atau variabel dikatakan reliabel jika memberikan nilai Cronbach Alpha $>0,70$

\section{Uji Asumsi Klasik}

Langkah berikutnya dalam pengujian hipotesis ini adalah dengan melakukan uji asumsi klasik. Uji asumsi klasik yang akan dilakukan adalah uji normalitas, uji multikolonieritas dan uji heteroskedastisitas.

\section{Uji Normalitas}

Menurut (Ghozali, 2016) uji normalitas dilakukan untuk menguji apakah dalam model regresi variabel independen dan variabel dependen atau keduanya mempunyai distribusi normal atau tidak. Apabila variabel tidak berdistribusi secara normal maka hasil uji statistik akan mengalami penurunan. Uji normalitas data dapat dilakukan dengan menggunakan One Sample Kolmogorov Smirnov yaitu dengan ketentuan apabila nilai signifikan diatas 0,05 maka data terdistribusi normal. Sedangkan jika hasil One Sample Kolmogorov Smirnov menunjukkan nilai signifikan dibawah 0,05 maka data tidak terdistribusi normal.

\section{Uji Multikolinieritas}

Menurut (Ghozali, 2016) pengujian multikolinearitas bertujuan untuk menguji apakah model regresi ditemukan adanya korelasi antar variabel bebas (independen). Untuk 
menemukan ada atau tidaknya multikolinearitas dalam model regresi dapat diketahui dari nilai toleransi dan nilai variance inflation factor (VIF). Tolerance mengukur variabilitas variabel bebas yang terpilih yang tidak dapat dijelaskan oleh variabel bebas lainnya. Jadi nilai tolerance rendah sama dengan nilai VIF tinggi (karena VIF $=1 /$ tolerance) dan menunjukkan adanya kolinearitas yang tinggi. Nilai cut off yang umum dipakai adalah nilai tolerance 0,10 atau sama dengan nilai VIF di bawah 10 .

\section{Uji Heteroskedastisitas}

Uji ini bertujuan untuk menguji apakah dalam sebuah model regresi terjadi ketidaknyamanan varian dari residual satu pengamatan ke pengamatan lain. Jika varian berbeda, disebut heteroskedastisitas. Salah satu cara untuk mengetahui ada tidaknya heteroskedastisitas dalam suatu model regresi linier berganda adalah dengan melihat grafik sccatterplot atau nilai prediksi variabel terikat yaitu SRESID dengan residual error yaitu ZPRED. Jika tidak ada pola tertentu dan tidak menyebar diatas dan dibawah angka nol pada sumbu y, maka tidak terjadi heteroskedastisitas. Model yang baik adalah yang tidak terjadi heteroskedastisitas (Ghozali, 2016).

\section{Pengujian Hipotesis}

\section{Analisis Regresi Linier Berganda}

Metode analisis pada penelitian ini menggunakan analisis regresi linear berganda (multiple linear regression). Metode penelitian ini digunakan karena lebih dari satu variabel independen. Analisis regresi linear berganda digunakan untuk menunjukkan arah hubungan antara variabel (total quality management, ketidakpastian lingkungan dan budaya organisasi) terhadap variabel dependen (kinerja manajerial). Persamaan regresi dapat dituliskan sebagai berikut:

$$
Y=\alpha+\beta_{1} X_{1}+\beta_{2} X_{2}+\beta_{3} X_{3}+e
$$

$\begin{array}{ll}\text { Keterangan: } & \\ \mathrm{Y} & \text { : Kinerja Manajerial } \\ \alpha & \text { : Konstanta } \\ \mathrm{X}_{1} & \text { : Partisipasi Penyusunan Anggaran } \\ \mathrm{X}_{2} & \text { : Gaya Kepemimpinan } \\ \mathrm{X}_{3} & \text { : Motivasi } \\ \beta_{1}, \beta_{2}, \beta_{3}, & \text { : Koefisien Regresi } \\ \mathrm{e} & \text { : Error }\end{array}$

\section{Uji Signifikansi Parameter Individual (Uji Statistik t)}

Uji statistik F mengukur goodness of fit, yaitu ketepatan fungsi regresi sampel dalam menaksir nilai aktual. Jika nilai signifikansi $\mathrm{F}<0,05$, maka model regresi dapat digunakan untuk memprediksi variabel independen. Uji statistik $\mathrm{F}$ juga menunjukkan apakah semua variabel independen atau bebas yang dimasukkan dalam model mempunyai pengaruh secara bersama-sama terhadap variabel dependen. Uji statistik $F$ mempunyai signifikansi 0,05 (Ghozali, 2016). Alternatif lain yang dapat digunakan untuk menerima atau menolak hipotesis yang dirumuskan, yaitu dengan melihat signifikansi ( $p$-value) masing- masing variabel bebas dengan taraf signifikansi $\alpha=0,05$. Apabila tingkat signifikan lebih kecil dari $\alpha$ $=0,05$, maka $\mathrm{H}_{0}$ ditolak atau $\mathrm{H}_{\mathrm{a}}$ diterima artinya secara parsial variabel bebas tersebut berpengaruh secara signifikan terhadap variabel terikat.

\section{Uji Koefisien Determinasi $\left(\mathbf{R}^{\mathbf{2}}\right)$}


Koefisien determinasi $\left(\mathrm{R}^{2}\right)$ dilakukan untuk mengukur seberapa jauh kemampuan model dalam menerangkan variasi variabel dependen (Ghozali, 2016). Nilai $\left(\mathrm{R}^{2}\right)$ berada 0 dan 1 semakin mendekati nilai 1 atau $100 \%$ maka akan semakin besar pengaruh variabel independen terhadap variabel dependen, untuk mengetahui besarnya variabel bebas dalam mempengaruhi variabel terikat dapat diketahui melelui nilai koefisien determinasi ditunjukkan oleh nilai Adjusted $R$ Square $\left(R_{2}\right)$ dipilihnya Adjusted $R$ Square agar tidak bias terhadap jumlah variabel independen yang dimaksudkan ke dalam model, karena tidak seperti $\left(\mathrm{R}_{2}\right)$ nilai Adjusted $R$ Square dapat naik atau turun apabila satu variabel independen ditambahkan kedalam model. Sedangkan $\mathrm{R}_{2}$ setiap tambahan satu variabel independen, maka $\mathrm{R}$ Square pasti meningkat tidak peduli apakah variabel tersebut berpengaruh secara signifikan terhadap variabel dependen. Kriteria indeks korelasi menurut (Ghozali, 2016) sebagai berikut

\section{HASIL DAN PEMBAHASAN Hasil Pengujian}

Penelitian ini menguji Pengaruh Partisipasi Penyusunan Anggaran, Gaya Kepemimpinan dan Motivasi Terhadap Kinerja Manajerial Survey Pada Kantor Wilayah Kementerian Agama Provinsi Jambi. Hipotesis pertama dalam penelitian ini adalah pengaruh partisipasi penyusunan anggaran, gaya kepemimpinan dan Motivasi secara simultan berpengaruh terhadap kinerja manajerial. Hipotesis kedua, partisipasi penyusunan anggaran terhadap kinerja manajerial. Hipotesis ketiga, pengaruh gaya kepemimpinan terhadap kinerja manajerial. Hipotesis keempat, pengaruh motivasi terhadap kinerja manajerial.

Hasil pengujian terhadap variabel partisipasi penyusunan anggaran menunjukkan bahwa nilai thitung variabel partisipasi penyusunan anggaran $\left(\mathrm{X}_{1}\right)$ 2,640 dengan angka signifikansi $0,012<0,05(\alpha=5 \%)$. Hal ini berarti bahwa partisipasi penyusunan anggaran berpengaruh terhadap kinerja manajerial. Hasil pengujian terhadap variabel gaya kepemimpinan menunjukkan bahwa nilai thitung variabel gaya kepemimpinan $\left(\mathrm{X}_{2}\right)$ 2,447 dengan angka signifikansi $0,019<0,05(\alpha=5 \%)$. Hal ini berarti bahwa gaya kepemimpinan berpengaruh terhadap kinerja manjerial. Hasil pengujian terhadap variabel gaya kepemimpinan menunjukkan bahwa nilai thitung variabel gaya kepemimpinan $\left(\mathrm{X}_{2}\right)$ 2,447 dengan angka signifikansi $0,019<0,05(\alpha=5 \%)$. Hal ini berarti bahwa gaya kepemimpinan berpengaruh terhadap kinerja manjerial.Hasil pengujian menunjukkan bahwa partisipasi penyusunan anggaran, gaya kepemimpinan dan motivasi secara simultan berpengaruh terhadap kinerja manajerial. Hasil penelitian ini sejalan dengan penelitian yang dilakukan oleh (Wulandari \& Riharjo, 2016) menunjukkan bahwa artisipasi penyusunan anggaran berpengaruh terhadap kinerja manajerial. Hal ini berarti bahwa penyusunan anggaran secara partisipatif memungkinkan manajer mempertimbangkan bagaimana membangun anggaran. Dengan adanya partisipasi tersebut, maka manajemen puncak dapat memperoleh informasi mengenai lingkungan yang sedang dan akan dihadapi perusahaan. Penelitian (Dewi et al., 2017) menunjukkan bahwa partisipasi penyusunan anggaran berpengaruh positif terhadap kinerja manajerial. Hal ini menunjukkan bahwa semakin tinggi keterlibatan para manajer dalam penyusunan anggaran maka kinerja manajerial akan semakin meningkat.

\section{PENUTUP}

Berdasarkan hasil analisis tentang pengaruh Partisipasi Penyusunan Anggaran, Gaya Kepemimpinan dan Motivasi berpengaruh terhadap Kinerja Manajerial maka dapat disimpulkan sebagai berikut : Partisipasi Penyusunan Anggaran, Gaya Kepemimpinan dan Motivasi berpengaruh terhadap Kinerja Manajerial pada Kantor Wilayah Kementrian Agama Provinsi Jambi. Partisipasi Penyusunan Anggaran berpengaruh terhadap Kinerja Manajerial 
pada Kantor Wilayah Kementrian Agama Provinsi Jambi. Gaya Kepemimpinan berpengaruh terhadap Kinerja Manajerial pada Kantor Wilayah Kementrian Agama Provinsi Jambi. Motivasi berpengaruh terhadap Kinerja Manajerial pada Kantor Wilayah Kementrian Agama Provinsi Jambi. Penelitian ini tidak terlepas dari keterbatasan dan kelemahan. Beberapa keterbatasan ini diharapkan dapat diatasi pada penelitian berikutnya, keterbatasanketerbatasan itu antara lain: Penggunaan self rating scale pada pengukuran kinerja manjerial dapat menimbulkan lineancy bias, dimana adanya kesalahan penilaian yang diakibatkan oleh sikap seorang penilai yang terlalu baik yang memiliki kecenderungan memberikan nilai evaluasi yang terlalu tinggi kepada setiap orang responden, dalam hal ini, diri sendiri. Minimnya sampel yang digunakan dalam penelitian ini mengakibatkan hasil penelitian terkendala ketika akan digeneralisasikan. Pada penelitian ini, masih banyak variabel-variabel lain yang diduga mempengaruhi kinerja manajerial pada Kantor Wilayah Kementerian Agama Provinsi Jambi namun belum diteliti.

\section{DAFTAR PUSTAKA}

Agusti, R. (2012). Pengaruh Partisipasi Penyusunan Anggaran Terhadap Kinerja Aparatur Pemerintah Daerah Dengan Dimoderasi Oleh Variabel Desentarlisasi Dan Budaya Organisasi (Studi Kasus Pada Pemerintah Kabupaten Bengkalis. Jurnal Ekonomi, 20(3), $1-15$.

Amanta, Komang Budi, Putra, I Made Pradana Adi, \& Werastuti, Desak Nyoman Sri. (2015). Pengaruh Komitmen Organisasi, Gaya Kepemimpinan, Ketepatan Skedul Penyusunan, Kejelasan Sasaran Anggaran, Partisipasi Penyusunan Anggaran Dan Akuntabilitas Publik Terhadap Kinerja Manajerial Pada Kantor Dinas Se-Kabupaten Karangasem. Akuntansi, 5.

Anthony, Robert N., \& Govindarajan, V. (2005). Sistem Pengendalian Manajemen.

Anthony, R. N., \& Govindarajan, V. (2003). Sistem Pengendalian Manajemen (Buku 2). Jakarta: Salemba Empat.

Apriansyah, G., Zirman, \& Rusli. (2014). Pengaruh Partisipasi Anggaran, Komitmen Organisasi, Kepuasan Kerja, Job Relevant Information Dan Budaya Organisasi Terhadap Kinerja Manajerial Pada Perhotelan Di Provinsi Riau. Jom Fekon, 1, 1-22.

Bangun, W. (2012). Manajemen Sumber Daya Manusia.

Dewi, Ni Ketut Sari Sukma, Putra, I Gede Cahyadi, \& Merawati, Luh Komang. (2017). Pengaruh Partisipasi Penyusunan Anggaran, Komitmen Organisasi Dan Motivasi Terhadap Kinerja Manajerial. Riset Akuntansi, 7.

Dr. Nur Indriantoro, M, S., \& Drs. Bambang Supomo, M. Si. (2014). Metodologi Peneltian Bisnis Untuk Akuntansi Dan Manajemen.

Ernis, F., Sularso, Raden Andi, \& Wardayati, Siti Maria. (2017). Pengaruh Partisipasi Anggaran Terhadap Kinerja Manajerial Melalui Komitmen Organisasi Dan Motivasi Sebagai Variabel Moderating (Studi Empiris Pada Perusahaan Manufaktur Di Jakarta Dan Tangerang). Bisnis Dan Manajemen, 11. Https://Doi.Org/10.24912/Ja.V19i1.119

Ghozali, I. (2016). Aplikasi Analisis Multivariate.

Hasan, \& Mowen. (2006). Akuntansi Manajmen.

Himawan, A. K., \& Ika, A. (2010). Pengaruh Komitmen Organisasi, Gaya Kepemimpinan Dan Job Relevant Information (Jri) Terhadap Hubungan Antara Partisipasi Anggaran Dan Kinerja Manajerial (Studi Empiris Pada Bpr Di Kota Semarang). Akses: Jurnal Ekonomi Dan Bisnis, 5.

Miftah Thoha. (2001). Kepemimpinan Dalam Manajemen.

Mulyadi. (2001). Akuntansi Manajemen.

P.Robbins, S., \& A.Judge, T. (2015). Perilaku Organisasi. 
Sanusi, A. (2011). Metodologi Penelitian Bisnis.

Sari, D. (2013). Pengaruh Partisipasi Anggaran Dan Akuntansi Pertanggungjawaban Terhadap Kinerja Manajerial Pt. Pos Indonesia. Akuntansi, 2. Https://Doi.Org/10.1515/Bchm2.1967.348.1.308

Syafriadi. (2015). Pengaruh Partisipasi Anggaran, Gaya Kepemimpinan Dan Komitmen Organisasi Terhadap Kinerja Manajerial (Studi Kasus Pada Universitas Pembangunan Pancabudi), 1 .

Tampi, B. J. (2014). Pengaruh Gaya Kepemimpinan Dan Motivasi Terhadap Kinerja Karyawan Pada Pt. Bank Negara Indonesia, Tbk. Journal "Acta Diurna” Volume Iii. No.4. Tahun 2014, Iii(4), 1-20.

Wibowo, \& M.Phil. (2013). Budaya Organisasi.

Wulandari, D. E., \& Riharjo, I. B. (2016). Pengaruh Penganggaran Partisipatif Terhadap Kinerja Manajerial Dengan Komitmen Organisasi Dan Gaya Kepemimpinan. Jurnal Ilmu Dan Riset Akuntansi, 5.

Yani, A. (2017). Pengaruh Partisipasi Anggaran, Budaya Organisasi, Dan Job Relevant Information Terhadap Kinerja Manajerial Pada Pemerintah Kabupaten Tulungagung. Cendikia Akuntansi, 5. 